\title{
Breaking Barriers
}

\section{New Insights into Airway Epithelial Barrier Function in Health and Disease}

\author{
Fariba Rezaee ${ }^{1}$ and Steve N. Georas ${ }^{2}$ \\ ${ }^{1}$ Division of Pediatric Pulmonary Medicine, Department of Pediatrics, and ${ }^{2}$ Division of Pulmonary and Critical Care Medicine, Department \\ of Medicine, University of Rochester Medical Center, Rochester, New York
}

\begin{abstract}
Epithelial permeability is a hallmark of mucosal inflammation, but the molecular mechanisms involved remain poorly understood. A key component of the epithelial barrier is the apical junctional complex that forms between neighboring cells. Apical junctional complexes are made of tight junctions and adherens junctions and link to the cellular cytoskeleton via numerous adaptor proteins. Although the existence of tight and adherens junctions between epithelial cells has long been recognized, in recent years there have
\end{abstract}

been significant advances in our understanding of the molecular regulation of junctional complex assembly and disassembly. Here we review the current thinking about the structure and function of the apical junctional complex in airway epithelial cells, emphasizing the translational aspects of relevance to cystic fibrosis and asthma. Most work to date has been conducted using cell culture models, but technical advancements in imaging techniques suggest that we are on the verge of important new breakthroughs in this area in physiological models of airway diseases.
Airway epithelial cells are an important part of the innate immune system. In addition to promoting mucociliary clearance, epithelial cells produce antimicrobial substances as well as chemokines and cytokines that recruit and activate other leukocytes (1). One overlooked component of epithelial defenses are apical junctional complexes (AJC) that form between neighboring cells and consist of the most apical tight junctions (TJ) and the underlying adherens junctions (AJ) (Figure 1). TJ are most apical and regulate paracellular transport of ions and certain molecules, whereas AJ are important for initiation and maintenance of cell-cell adhesion $(2,3)$. Epithelial TJ and $\mathrm{AJ}$ are involved in numerous signal transduction cascades and interact to establish apical-basal epithelial cell polarity $(4,5)$. Dysfunction of epithelial junctions is increasingly linked to airway diseases and may predispose to infections, but a comprehensive picture of the relationship between junctional integrity and antimicrobial defenses is lacking. In this review, we focus on the structure and function of airway epithelial TJ and give examples of junctional regulation by environmental exposures. Dysfunction of alveolar TJ contributes to pulmonary edema and lung injury, but this topic is beyond the scope of this review (for reviews see Ref. 6-8). Our understanding of AJC structure and function comes largely from model epithelia and studies of nonpulmonary tissues, and although the basic principles of AJC organization apply to most epithelial cells, we mention examples of lung-specific junctional expression and/or regulation.

\section{Early Studies of TJ and Current Models}

Intercellular junctions were first identified using light microscopy, but the advent of electron microscopy (EM), especially freeze- fracture techniques, was a key step forward. By EM, TJ appear as linear strands just below the apical membrane and run in parallel bands. The first systematic analysis of airway epithelial tight junction morphology by EM was reported in 1992 (9). In this paper, Godfrey and colleagues used freeze-fracture EM with normal human lung tissue and observed approximately 11 strands per epithelial cell, with a similar distribution in main and lobar bronchi (9). Because of the challenges in quantifying junctional morphology systematically in multiple orders of branching airways, it was difficult to determine whether strand number or organization varied based on location within the tracheobronchial tree. In a subsequent paper, Jeffery and colleagues compared airway junctional morphology in lungs from subjects with and without cystic fibrosis (CF) and found no significant difference in strand number but found some differences in junctional complexity

(Received in original form December 20, 2013; accepted in final form January 22, 2014)

This work was supported by National Institutes of Health grants R01 HL071933 and P30 ES001247 (S.G.) and K12 HD068373.

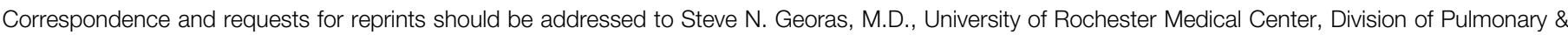
Critical Care Medicine, Professor of Medicine, 601 Elmwood Avenue, Box 692, Rochester, NY14642-8692. E-mail: Steve_Georas@urmc.rochester.edu

Am J Respir Cell Mol Biol Vol 50, Iss 5, pp 857-869, May 2014

Copyright $(2) 2014$ by the American Thoracic Society

Originally Published in Press as DOI: 10.1165/rcmb.2013-0541RT on January 27, 2014

Internet address: www.atsjournals.org 


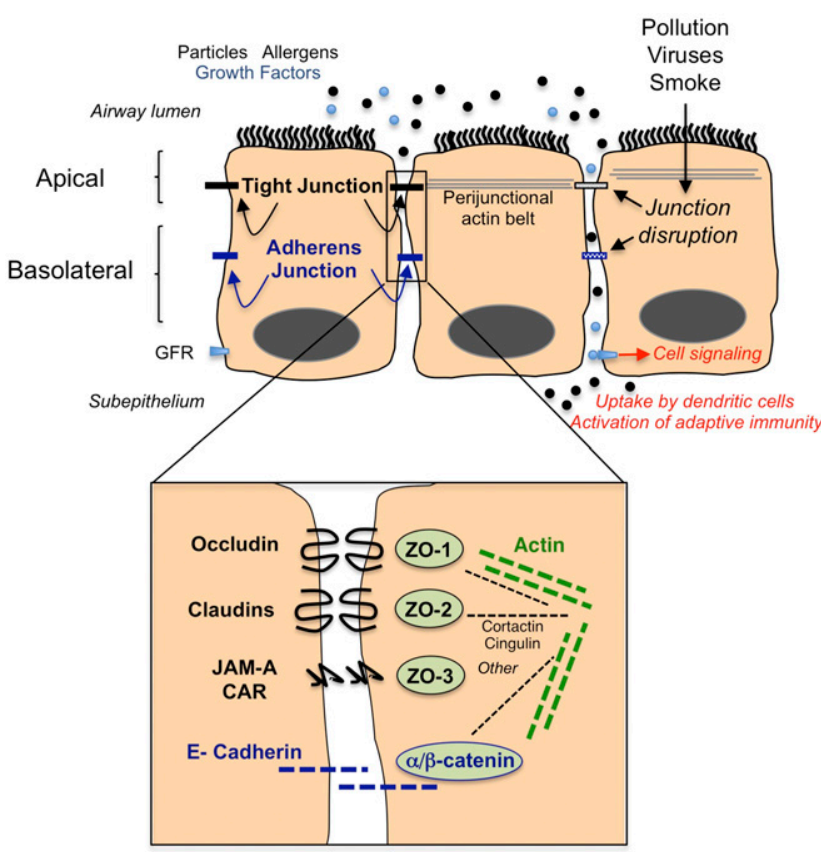

Figure 1. Cartoon diagram demonstrating organization of junctional structures in the airway epithelium including tight junctions (black) and adherens junctions (b/ue). Certain environmental exposures lead to dysfunction of epithelial junction, resulting in greater outside/in permeability. The figure demonstrates the potential for barrier dysfunction to lead to cell signaling because it allows apical cytokines and growth factors, which may be constitutively present in epithelial lining fluids (light blue dots), to interact with basolateral receptors (light blue rectangle labeled GFR [growth factor receptor]). In the presence of intact epithelial junctions, these ligand/receptor interactions are prevented. Barrier dysfunction also allows penetration of luminal particles and antigens into the subepithelial space, where they encounter innate immune cells that initiate inflammation and immune reactions. The fate of subepithelial particles is complex; subepithelial particles may, depending on size and shape, translocate via afferent lymphatics to the pleural space, regional lymph nodes, or the blood stream (not shown). The inset shows an enlarged schematic of protein-protein interactions in tight junctions (black text) and adherens junctions (blue text), including ability of zonula occludens (ZO) proteins to interact with intracytoplasmic domains. The inset also indicates that junctional proteins are linked to the actin cytoskeleton (green dashed line) via several potential adaptor proteins (black dashed line). This figure is meant to be illustrative and not comprehensive and does not include many other potential interacting partners or other molecules that contribute to barrier integrity or cell polarity. CAR, coxsackie adenovirus receptor; JAM-A, junctional adhesion molecule.

(e.g., disorganized strands that sometimes extended below the typical apical belt) (10). The functional significance of disorganized tight junction strands was not investigated in that report.

Barrier function is now usually studied by growing epithelial cells in vitro on semipermeable membranes. This approach has strengths and weaknesses. Strengths include the ability (1) to analyze junctional structure and function in the same cells, (2) to identify signal transduction cascades involved in junctional regulation, and (3) to conduct gain-of-function or loss-offunction experiments targeting specific AJC components. Two general approaches are used to study junction function: (1) permeability to small ions can be measured by analyzing transepithelial electrical resistance (TEER), and (2) permeability to probes of different sizes and shapes can be estimated by measuring flux across the monolayer. This is typically expressed normalized to surface area and concentration as apparent permeability: $\mathrm{P}_{\text {app }}=\mathrm{F} /\left(\mathrm{S} \times \mathrm{A}_{0}\right)$, where $\mathrm{F}=$ flow rate, $\mathrm{S}=$ surface area, and $\mathrm{A}_{0}=$ starting concentration (11). Molecules that traverse epithelia paracellularly via TJ should demonstrate linear and nonsaturable permeability. Weaknesses of studying model epithelia in vitro include the inability to fully recapitulate the complex structure of surface epithelia including nonepithelial cells in tissue culture. This concern can be mitigated by studying primary epithelial cells differentiated at air-liquid interface (ALI), which closely resemble epithelial cells in situ (12). However, because junctional structure is intimately associated with cell differentiation status, it can be challenging to understand the directionality of a given perturbation in vitro (i.e., did junctional structure/function change because of alterations in cell differentiation?). The ability to study intact epithelial sheets or airway explants can circumvent some of these caveats (13).

Disruption of barrier integrity enhances outside/in translocation of inhaled particles into the subepithelial space, where they encounter innate immune cells and lead to airway inflammation and immune responses (Figure 1). In addition, by affecting the polarized distribution of cell surface receptors and their ligands, AJC dysfunction can activate intracellular signal transduction cascades and lead to secretory activity and cell activation (14-16).

Although our understanding of junction structure has expanded enormously, there is no comprehensive model to fully explain how changes in junction structure affect paracellular permeability. Current thinking is that intercellular junctions are not static resistors but rather dynamic structures with discrete probabilities of being open or closed $(3,17)$. One recent model proposes that there are two pathways for paracellular movement of molecules (3): (1) the claudin-containing "pore," which controls movement of ions in a charge and size-selective manner, and (2) the "leak" pathway, which allows limited movement of larger macromolecules. It may seem counterintuitive that macromolecular flux can increase without a decrease in TEER, although this is well documented in the literature (18-21).

TEER measures instantaneous ion flux, whereas permeability to tracers is typically measured over hours. Consequently, if macromolecules move through sequential $\mathrm{TJ}$ strand breaks organized in series and if at least one strand blocks the paracellular space during TEER measurement, then instantaneous ion permeability might not be affected, whereas macromolecular permeability increases (the "revolving door model"). Although the molecular basis for this model remains to be determined, it reinforces the notion that AJC are dynamic and potentially compartmentalized structures. Deciphering the structure of AJC in their native membrane context will 
help provide clarity in this area, although this will be a challenging task. Because TEER can be dissociated from changes in junctional structure and function, it seems reasonable to conclude that multiple experimental approaches (e.g., TEER, permeability, and microscopy) should be used to provide a complete assessment of AJC function in different models.

\section{Components of the Lung Barrier Including AJC}

TJ are comprised of intracellular and extracellular components, many of which were discovered by the late Shoichiro Tsukita (22). There are three major types of transmembrane TJ proteins: (1) members of claudin family, (2) tight junction-associated MARVEL protein family members (i.e., occludin, tricellulin, and MARVELD3), and (3) immunoglobulin-like proteins, such as junctional adhesion molecule (JAM) and coxsackie adenovirus receptor (CAR) (23). E-cadherin and members of the nectin family represent the major transmembrane proteins of epithelial AJ (24). Peripheral membrane proteins form the cytosolic plaque of TJ and AJ, where they cluster and stabilize adhesive components of the AJC, including the zonula occludens ( $\mathrm{ZO})$ proteins that link the intracellular domains of TJ components with actin-binding proteins (e.g., cortactin, $\alpha$-catenin, vinculin, and $\alpha$-actinin) and the cellular cytoskeleton via mechanisms under active study. Other components of the cytosolic plaque linking TJ and E-cadherin with the cytoskeleton include afadin, cingulin, $\beta$-catenin, and p120 catenin.

\section{Claudins}

Expression and function in the lung. Since the original discovery of claudin-1 by Tsukita and colleagues in 1998 (25), at least 27 claudin family members have been identified. Although no crystal structures have been reported to date, mutagenesis and domain-swapping experiments have provided insights into claudin structure/ function relationships $(26,27)$. Claudins are predicted to be tetraspanning molecules with short $\mathrm{N}$-terminal and longer $\mathrm{C}$ terminal cytoplasmic domains and two extracellular loops. Homo- and heterotypic aggregation (the latter especially with claudin-3) between both extracellular loops is thought to be crucial for claudin-claudin interactions in the tight junction, whereas the first extracellular loop may be more important in controlling paracellular ion permeability (28). Claudins are expressed in a tissue-specific manner and can be broadly categorized into two groups. First, some claudins increase paracellular permeability ("pore forming" or "leaky" claudins). For example, in intestinal epithelial cells and models of Th2 inflammation, IL-13, and Stat6 cause epithelial barrier dysfunction in part by inducing expression of the leaky claudin-2 (29). However, we recently showed using 16HBElo- airway epithelial cells that IL-4 and IL-13 induce airway epithelial barrier dysfunction without inducing claudin-2 expression (30). Whether claudin-2 is expressed in the airway is controversial (see below). Second, other claudins interact in a homo- or heterotypic manner to promote barrier integrity (e.g., claudin-1).

Different claudins are expressed throughout the respiratory tract, and their cell-type expression and contribution to lung diseases is an active area of research. Excellent recent reviews are available that summarize the expression and potential function of lung claudins in detail $(7,8,31)$. There appear to be differences in claudin expression depending on location within the tracheobronchial tree (32-34). This is an emerging area where there is lack of consensus and some discrepancies among published studies, likely reflecting differences in species studied and staining techniques used to detect claudin expression in tissues. In one early study of frozen sections, freshly excised human airways were found to express claudin-1, $-3,-4,-5$, and -7 , which differed in their cellular localization (e.g., apical vs. lateral membrane [32]). Claudin-2 protein was not detected in that report (32), whereas a later study of formalin-fixed tissue detected intense bronchiolar staining of claudin-2 (as well as claudin-1, -3, -4, and -7) (35). Claudin-3 is expressed by ciliated upper airway and by type II alveolar epithelial cells, where it may serve a barrier disruptive function at baseline (36). In the alveolus, up-regulation of claudin-4 has emerged as a potentially protective response to lung injury (reviewed in Ref. 37), but less is known about the role of claudin- 4 in the airway. Claudin- 3 and -4 are targeted by clostridium perfringes exotoxin (38), and the ability to disrupt claudins and other AJC components may prove useful for drug delivery or airway gene therapy $(39,40)$.

Although claudin-5 was detected in freshly excised airway samples (32), it was not detected in human airway epithelial cells differentiated in vitro at ALI (which preferentially expressed claudin-1 and -4) (41). In a human CF airway epithelial cell line (IB3.1), overexpression of claudin-5 enhanced airway epithelial permeability to different size dextrans (32). This result was surprising because claudin-5 is an essential component of the endothelial blood-brain barrier (42). Recent studies also demonstrated a crucial protective role for claudin-5 in lung microvascular endothelial cells during influenza and HIV infection (43). Claudin-5 it is not expressed by high endothelial venules in lymph nodes, an important site of lymphocyte egress from the circulation, suggesting that these blood vessels may be leaky at baseline (44). Although more research is needed about the role of claudin-5 in the airway, these examples raise the possibility that the same TJ component might have different functions depending on the cellular and tissue context in which it is expressed. The splice variant claudin-18.2 appears relatively specific for the lung, where it has been implicated in maintaining alveolar barrier integrity in models of lung injury (8). In the airway, a preliminary study indicated that claudin-18 was reduced in asthma and inhibited by the Th2 cytokine IL-13 (45).

Lessons from gene-targeted mice. Although different claudin-deficient mice have been reported, none of the publications to date has reported lung-specific phenotypes. This may reflect redundancy among claudin family members, the possibility that some subtle developmental defects were overlooked, or the possibility that gene-targeted mice were not investigated in models of lung diseases (46). Some examples of gene-targeted mice are shown in Table 1 (42, 47-61).

Evidence from human diseases. Genetic mutations in claudin-1 cause a rare disorder characterized by neonatal icthyosis and sclerosing cholangitis (62). Other examples of genetic mutations leading to human diseases include familial hypomagnesemia and hypercalcuria with nephroaclcinosis and claudin-16 and -19 (63) and autosomal 
Table 1: Lessons from Gene-Targeted and Transgenic Mice

\begin{tabular}{|c|c|c|}
\hline Gene & Phenotype & Reference \\
\hline Claudin-1 & $\begin{array}{l}\text { Early lethality, excessive transepidermal } \\
\text { water loss }\end{array}$ & 47 \\
\hline Claudin-2 & Increased $\mathrm{FE}_{\mathrm{Na}}$ after saline challenge & 48 \\
\hline Claudin-4 & $\begin{array}{l}\text { Urothelial hyperplasia and lethal } \\
\text { hydronephrosis }\end{array}$ & 49 \\
\hline Claudin-5 & Increased CNS permeability to small molecules & 42 \\
\hline Claudin-14 & Cochlear hair degeneration, deafness & 50 \\
\hline Claudin-15 & Megaintestine; glucose malabsorption & 51,52 \\
\hline \multirow[t]{2}{*}{ Occludin } & $\begin{array}{l}\text { Normal intestinal barrier function; diverse } \\
\text { histologic abnormalities }\end{array}$ & 53 \\
\hline & $\begin{array}{l}\text { Knockout T cells with delayed accumulation } \\
\text { and migration in intestine }\end{array}$ & 54 \\
\hline ZO-1 & $\begin{array}{l}\text { Lethal ED 10.5-11.5 } \\
\text { Disturbed angiogenesis }\end{array}$ & 55 \\
\hline ZO-2 & $\begin{array}{l}\text { Lethal ED } 7.5 \\
\text { Decreased proliferation and increased apoptosis } \\
\text { Decreased blood-testis barrier in blastocyst chimeras }\end{array}$ & 56,57 \\
\hline ZO-3 & None & 56,58 \\
\hline CAR & $\begin{array}{l}\text { Intestinal dilation, trend to decreased barrier function } \\
\text { AV block }\end{array}$ & 59 \\
\hline JAM-A & $\begin{array}{l}\text { No effect on steady-state or LPS-induced lung permeability } \\
\text { Decrease in LPS-induced inflammation due to } \\
\text { inhibited neutrophil extravasation } \\
\text { Increased intestinal permeability }\end{array}$ & $\begin{array}{l}60 \\
61\end{array}$ \\
\hline
\end{tabular}

Definition of abbreviations: CAR, coxsackie adenovirus receptor; CNS, central nervous system; ED, embryonic day; $\mathrm{FE}_{\mathrm{Na}}$, fractional excretion of sodium; JAM-A, junctional adhesion molecule; $\mathrm{ZO}$, zonula occludens.

recessive deafness and claudin-14 (64). In skin biopsies of subjects with atopic dermatitis, expression of claudin- 1 is reduced in association with increased skin permeability (65), which may confer risk for epicutaneous allergen sensitization (66). The potential role of claudins and other AJC components in airway barrier defects in asthma is considered further below.

\section{Occludin}

Structure and function. Occludin was identified before claudin-1 by Furuse and colleagues while characterizing a monoclonal antibody that recognized a tight junction-associated molecule in hepatocytes (67). Together with tricellulin and marvelD3, occludin shares a conserved "marvel" domain, which consists of four hydrophobic segments predicted to form tightly packed transmembrane $\alpha$-helices. The intracellular $\mathrm{N}$ - and C-termini are subjected to numerous posttranslational modifications, which are thought to affect interactions with scaffold components in the AJC (68). For example, the occludin Cterminus can be phosphorylated by protein tyrosine kinases, serine/threonine kinases, and protein kinase $\mathrm{C}$ family members, which regulate association with $\mathrm{ZO}-1$ and perijunctional actin filaments (69-72). The crystal structure of the occludin Cterminus revealed a motif similar to RNA polymerase elongation factors (73). Key studies using photobleaching followed by recovery demonstrated that the cellular pools of claudin-1, ZO-1, and occludin are distinct, with occludin being significantly less stable than claudin (74).

After two decades of investigation, the function of occludin in the AJC remains enigmatic. In cells that normally lack TJ (e.g., fibroblasts), expression of claudin-1 or -2 was sufficient to recapitulate $\mathrm{TJ}$ structure and function (75), whereas the same did not hold true for occludin (76). In addition, epithelial barrier function appears to be intact in occludin-null mice (see below). Thus, occludin is neither sufficient nor necessary for AJC function, and by interacting with $\mathrm{ZO}-1$ and the actin cytoskeleton, occludin is often suggested to have a regulatory role in the AJC.

Occludin overexpression in MadinDarby canine kidney cells (MDCK) cells augments TEER but paradoxically also enhances permeability to $4-\mathrm{kD}$ dextran $(19,20)$. Using a tetracycline-inducible system, Van Itallie and colleagues reported that increasing occludin expression by $\sim 4$ fold enhanced the barrier-disruptive effects of the cytokines IFN- $\gamma+$ TNF- $\alpha$ in MDCK II cells, as assessed by monitoring permeability to $3-\mathrm{kD}$ dextran (77). Furthermore, deletion mutants or chimeric constructs lacking the occludin extracellular domains demonstrated reduced paracellular permeability to mannitol (and other tracers) in MDCK cells (78). One interpretation of these studies is that occludin actively promotes the paracellular flux of macromolecules. However, caveats apply to these overexpression studies because ectopically expressed occludin might not integrate similarly in the apical membranes as native protein, and overexpressed occludin might act in a dominant-negative manner. Van Itallie and colleagues suggested that overexpressed occludin disrupted barrier structures by promoting caveolin-dependent endocytosis (77). These apparent barrier disruptive effects of occludin might be cell-type specific because small interfering RNA (siRNA) knockdown of occludin increases paracellular flux of mannitol (and other tracers) in Caco-2 cells, which originated from a human colon carcinoma (79). Furthermore, in human airway epithelial cells, apical application of a synthetic peptide corresponding to the first extracellular loop (a.a. 90-103) reduced TEER and enhanced permeability to 70and $2,000-\mathrm{kD}$ dextrans (80). This result must be interpreted with caution because occludin peptides were active at high concentrations that also induced cell cytotoxicity (80). In Caco-2 cells, similar peptides enhanced permeability to mannitol without causing significant cell toxicity (81). Future studies of additional cell types, including primary airway epithelial cells at ALI, are needed to help define the precise role of occludin in airway barrier physiology.

Occludin in lung models. Despite the confusing results obtained using occludin gain-of-function and loss-of-function approaches in vitro, reduced expression of occludin has been associated with disrupted airway barrier function in several model systems. For example, Olson and colleagues reported that $\mathrm{H}_{2} \mathrm{O}_{2}$ disrupted barrier function in 16HBElo- cells and primary mouse tracheal epithelial cells in association 
with markedly reduced occludin expression (82). This result is in keeping with the ample evidence from other experimental models that occludin is sensitive to cell redox status (see Ref. 83 for recent comprehensive review). Airway epithelial $\mathrm{H}_{2} \mathrm{O}_{2}$-induced barrier dysfunction was prevented by exposure to hypoxia in a HIF- $1 \alpha$-dependent manner (82). Taken together with results from experimental colitis models (84, 85 ), these data suggest that HIF- $1 \alpha$ promotes epithelial barrier integrity after diverse insults.

Gene-targeted mice. Two publications describe the phenotype of occludin-null mice, which were generated by homologous recombination targeting exon 3 (the first transmembrane domain to the second extracellular loop) (Table 1). The structure and function of TJ, as analyzed in different tissues including intestine, urinary bladder, and stomach, was found to be indistinguishable from wild-type controls $(53,86)$. Lung barrier function was not described in these reports. Although epithelial barrier function was apparently intact, genetic deficiency of occludin had significant effects on fertility and postnatal growth and resulted in histological evidence of chronic inflammation in the stomach, calcification in the brain, testicular atrophy, and thinning of the compact bone (53). Thus, the function of occludin in regulating paracellular permeability and epithelial integrity in vivo requires further study. Mice in which the expression of occludin can be regulated in a time-dependent and tissue-specific manner should provide more insights into the role of this molecule in the future.

Other functions of occludin. In addition to regulating paracellular permeability, occludin has other functions. In human hepatocytes, occludin (in addition to claudin-1 and other factors) is a hepatitis $\mathrm{C}$ viral entry factor (87-89). Yu and colleagues noted that the exclusion of cells from confluent MDCK monolayers was markedly reduced after siRNA-mediated occludin knockdown (i.e., reduced numbers of "floaters" in tissue culture) and concluded that occludin is involved in sensing and excluding apoptotic cells from epithelial monolayers (90). There is an emerging role for occludin in immune cell migration, specifically neutrophil transepithelial migration (91), and intraepithelial migration of $\gamma \delta$-T cells in the intestine (54). Huber and colleagues found that the migration of neutrophils across an MDCK monolayer was regulated by the occludin N-terminus independently of effects on TEER or paracellular permeability to mannitol (91). Recently, Edulblum and colleagues used intravital imaging with novel transgenic mice and found that $\gamma \delta$-intraepithelial lymphocytes, which are involved in immune surveillance, expressed occludin and appeared to migrate within the epithelium via homotypic interactions with occludin-expressing epithelial cells (54). These studies suggest that, in addition to its role in barrier regulation, occludin may act like an adhesion molecule during tissue inflammation.

\section{Zonula Occludens}

Structure and function. ZO-1 was identified in 1986 as a TJ-associated protein in several epithelia (92) and is now known to be a member of the membrane-associated guanlyate kinase (MAGUK) family $(93,94)$, together with ZO-2 (95) and ZO-3 (96). The MAGUK family contains $\mathrm{PDZ}, \mathrm{SH} 3$, and inactive guanylate kinase domains, the latter two of which interact in ZO-1 as a shared module $(97,98)$. ZO proteins are expressed in a tissue-specific manner and contain numerous domains capable of protein-protein interactions with other TJ components, the actin cytoskeleton, and other signaling molecules $(99,100)$ (for a recent review see Ref. 101). Thus, ZO proteins are key components of the scaffold that is thought to cluster and stabilize TJ in the apical membrane. $\mathrm{ZO}$ proteins also contain conserved nuclear localization sequences and translocate in and out of the nucleus in a cell-cycle-dependent manner $(102,103)$. The function of nuclear $\mathrm{ZO}$ is not well understood, but in some contexts it may act as a transcriptional repressor (104).

ZO and the scaffold. ZO family members have been studied extensively in model epithelia, where they show some redundancy in function. Similar to the case of occludin, ZO family members appear to exert cell-type-specific effects on AJC structure and function. For example, in Eph4 cells, double deficiency of ZO-1 and ZO-2 did not affect cell polarity but led to reductions in TJ strand formation and TEER as well as enhanced paracellular flux (105). Using an inducible small hairpin RNA strategy in MDCK cells, dual ZO-1/ZO-2 knockdown led to markedly increased permeability but no changes in TEER (106). Whereas wildtype MDCK cells excluded probes $>4$ angstroms $(\sim 0.4 \mathrm{~nm})$, size selectivity was lost in ZO1/ZO2 DKO cells (106). These investigators also observed that knockdown of ZO-1/ZO-2 resulted in marked expansion of the perijunctional actin cytoskeleton especially near AJ, reinforcing the notion that $\mathrm{TJ} / \mathrm{AJ}$ structure is interrelated and suggesting that $\mathrm{ZO}-1 / \mathrm{ZO}-2$ play a broader role in morphogenesis (106).

Knockout mice. Gene-targeted mice uncovered a unique role for ZO family members during embryogenesis (Table 1). Whereas ZO-1 and ZO-2 deficiency resulted in embryonic lethality, $\mathrm{ZO}$ 3 -deficient mice were viable and apparently normal (55-58). This may reflect the fact that ZO-1 and ZO-2 are expressed in endothelial and epithelial cells, whereas ZO-3 is restricted to epithelia, where its function may be compensated by other family members.

Little is known about the expression and function of $\mathrm{ZO}$ proteins in the airway, although several studies have documented associations between alterations in $\mathrm{ZO}-1$ expression and decreased barrier function in different models. For example, we recently reported that treatment of human bronchial epithelial cells with polyI:C, a double-stranded RNA, or infection with respiratory syncytial virus (RSV) induces marked disassembly of ZO-1-containing AJC from the cell surface $(107,108)$. Using primary cells and the 16HBElo- cell line, we found that the barrier disruptive effects of polyI:C and RSV were dependent on protein kinase D (PKD) and were not associated with marked changes in ZO-1 expression but rather interfered with its assembly into the AJC. Grumbach and colleagues reported that in $16 \mathrm{HBE}$ cells lipoxin A4 enhanced TEER in association with increased $\mathrm{ZO}-1$ expression (109). The potential role of airway epithelial ZO-1 dysfunction in asthma is considered below.

\section{Other Molecules}

Other molecules contribute to the macromolecular AJC in the airway epithelium, and it seems likely that new information will be forthcoming as 
new models are developed. Here we highlight a few recent observations potentially of relevance to airway biology research.

MARVEL family. As its name implies, tricellulin is enriched at junctions formed by three cells and is a member of the MARVEL family (110). Mutations in the tricellulin gene are associated with nonsyndromic deafness in humans (111). Tricellulin is widely expressed, including in the inner ear, skin, stomach, and nasal epithelial cells (112), but its expression in the lung has not been well studied. Tricellulin is also expressed by nonepithelial myeloid cells (e.g., brain microglia [113]), but whether myeloid cells express this molecule in the lung requires further study. The expression and function of the remaining MARVEL family member MARVELD3 in the lung has not been previously reported to our knowledge. A recent genome-wide association study identified an intergenic single-nucleotide polymorphism in MARVELD3 associated with malaria resistance (114), underscoring the importance of AJC in host-pathogen interactions.

Immunoglobulin family members. It seems likely that further study of JAM and CAR will uncover roles for these molecules in airway diseases. In polarized human airway epithelial cells, JAM-A is expressed on the basolateral but not apical surfaces, where it can promote reovirus entry (115). JAM-A deficiency in mice does not alter steady-state or LPS-induced lung permeability (assessed by bronchoalveolar lavage protein content or wet:dry ratio) (60) but does enhance intestinal permeability (assessed by measuring absorption of 3,10 , and $40 \mathrm{kD}$ dextran into the bloodstream) (61). Although lung permeability was not affected in JAM-A-deficient mice, LPSinduced neutrophil emigration into alveoli was strikingly attenuated (60). The effects of JAM-A deficiency on leukocyte recruitment to proximal airways or on airway epithelial permeability per se have not been systematically investigated to our knowledge. Multiple CAR isoforms are expressed by airway epithelial cells that differ in their localization to the apical versus basolateral membrane (116). A seminal early study established that binding of adenovirus to CAR on airway epithelial cells caused AJC disassembly, leading to paracellular leak and escape of virus (117), which may be a strategy used by viruses to promote infectivity. In the skin, heterotypic interactions between CAR (on keratinocytes) and JAM-L (expressed by a subset of $\gamma \delta$-T cells) was shown to help initiate immune responses after epidermal injury $(118,119)$. Whether similar events occur after epithelial injury and barrier disruption in the lung is not known.

AJ molecules. Recent insights into the roles of AJ components in epithelial barrier structure and function were obtained using different mouse models. Targeted deletion of $\beta$-catenin in club cells (Clara cells) did not significantly affect epithelial development or repair after naphthalene exposure (120). However, $\beta$-catenin may be involved in neutrophil transmigration across alveolar epithelial cells, which by itself is sufficient to cause transient barrier dysfunction (121). Deletion of p120 (exons 3-8) was achieved in the intestine by breeding floxed mice with mice expressing Cre recombinase driven by the villin promoter, which resulted in the disruption of $\mathrm{AJ}$ and $\mathrm{TJ}$ in a variegated manner (122). This partial loss of p120 inhibited the assembly of AJ and TJ into the AJC and resulted in spontaneous intestinal inflammation probably due to translocation of luminal microbes (122). It will be interesting to determine if p120 has similar roles in the airway, but one prediction is that constitutive deletion in the lung may be better tolerated than in the intestine due to lower microbial burden.

Polarity proteins. Emerging evidence points to an important role for polarity proteins in the proper assembly of tight and AJ (123). Most research to date has been conducted in model organisms (e.g., Caenorhabditis elegans and Drosophila melanogaster), where different families of proteins have been identified including the PAR complex (containing six par genes and protein kinase $\mathrm{C} 3$ ), the Crumbs complex (composed of Crumbs, PALS1, and PATJ), and the Scribble complex (containing scribble, Dlg, and Lgl). Polarity proteins are essential for proper morphogenesis and maintenance of apical versus basolateral polarization. The relationship between polarity proteins and AJC structure/ function is a rapidly expanding area of research (124), but very little is known about their role in the lung $(125,126)$. Crumbs3 was recently shown to be important for epithelial development and viability in mice. Crumbs3 gene-targeted mice died at birth with lungs filled with proteinaceous debris, although alveolar TJ structure appeared intact (127). More research into the expression and function of polarity proteins in the lung is needed and may provide insights into epithelial barrier regulation in disease states.

\section{Inducible Airway Epithelial Barrier Dysfunction: Role of Air Pollution and Viruses}

Increased epithelial permeability is a long-recognized hallmark of mucosal inflammation, although the causes and molecular mechanisms involved have been studied only recently. Loss of junctional components such as E-cadherin occurs in epithelial-mesenchymal transition, but the relationship between this complicated process and inflammation-induced AJC disassembly is beyond the scope of this review (for review see Ref. 128 and 129). Three general mechanisms of inducible AJC dysfunction have emerged, which are not mutually exclusive: (1) apical junctions can be degraded by extracellular proteases that are released by inflammatory cells, (2) the expression of AJC components can be silenced at the transcriptional or posttranscriptional level, and (3) junction complexes can be disrupted without affecting gene expression per se via internalization or shedding of AJC components. In models of inflammatory bowel disease, junctional endocytosis has emerged as an important mechanism of intestinal epithelial barrier dysfunction. The molecular mechanisms of junctional endocytosis are complex and involve caveolin-1-dependent pathways, (macro)pinocytosis, and clathrin-dependent mechanisms as well as cytoskeletal remodeling (for reviews see Ref. 130 and 131). In intestinal epithelial cells, caveolin1-dependent endocytosis involving myosin motors underlies TJ disruption in response to inflammatory cytokines and other insults (132-134).

Several environmental exposures have been shown to enhance airway epithelial permeability without inducing cytotoxicity. These include air pollution components, respiratory viruses, allergens, and cigarette smoke. Schamberger and colleagues recently reported that cigarette smoke extract 
reduced barrier integrity in human airway epithelial cells by dissociating $\mathrm{ZO}$ proteins from the AJC (135). In this section, we highlight examples of air pollution- and virus-induced airway barrier dysfunction but caution that some effects were observed at very high concentrations that likely overestimate real-world exposures (Table 2) (108, 136-143).

\section{Air Pollution}

In 1994, Yu and colleagues documented the barrier-disruptive effects of ozone exposure (0.5-0.8 ppm) on canine bronchial epithelial cells (136) (Table 2). A subsequent study showed similar effects of lower ozone concentrations (0.1-0.4 $\mathrm{ppm}$ ) and showed that primary bronchial epithelial cells obtained from subjects with asthma were more sensitive than those from control subjects (137). High concentrations of diesel exhaust particles and carbon nanotubes were shown to reduce TEER and/or to increase permeability in different lung epithelial cell lines (Table 2). Recently, Thevenot and colleagues exposed neonatal mouse airway epithelial at ALI to a synthetic mixture of ultrafine particles and observed loss of barrier integrity in association with decreased E-cadherin expression (144). The authors extended their observations to in vivo exposures and, using a lineage tracing strategy, concluded that particulate exposure induced epithelial-mesenchymal transition. However, exposure of healthy volunteers to particulate matter (PM)rich air did not increase "outside/in" permeability as assessed by clearance of 99mTc-labeled DTPA (145).

Repeated exposure to PM may be needed to induce barrier disruption. Sidhaye and colleagues found that two applications of PM were required to enhance normal human bronchial epithelial cell permeability in vitro (16). Thus, more research is needed to determine how inhaled pollutants affect epithelial barrier integrity. In future studies, it will be important to look for interactions between pollution components and other environmental exposures and to study vulnerable subjects who may be at more risk of adverse effects from air pollution.

\section{Respiratory Viruses}

Infections with some viruses leads to barrier dysfunction by causing epithelial cell death due to direct cytopathic effect or indirectly via immune cell cytotoxicity (e.g., severe influenza). However, a body of research has uncovered novel roles for respiratory viruses in causing apical junctional disruption without inhibiting cell viability. These studies complement the established notion that junctional components can serve as receptors for viruses and promote cell entry (e.g., Coxsackie B, adenoviruses, and reoviruses) (146-148). Because junctional dysfunction can facilitate virus escape and expose TJ and AJ molecules on the basolateral epithelial surface, virus-induced AJC disruption probably represents an evolutionary strategy that facilitates viral replication $(117,149)$. The molecular mechanisms by which respiratory viruses decrease junctional integrity have been studied only recently. In Caco-2 cells,

Table 2: Inducible Airway Epithelial Barrier Disruption by Air Pollutants and Respiratory Viruses

\begin{tabular}{|c|c|c|c|c|c|c|}
\hline Stimulus & Cells & TEER & $\begin{array}{l}\text { Permeability } \\
\text { (Tracer) }\end{array}$ & AJC expression & Notes & Reference \\
\hline \multicolumn{7}{|l|}{ Air pollution } \\
\hline Ozone (0.5-0.8 ppm) & CBE & Decreased & $\begin{array}{l}\text { Increased } \\
\quad(\text { mannitol) }\end{array}$ & ND & & 136 \\
\hline Ozone (0.1-0.4 ppm) & PBEC & Decreased & $\begin{array}{l}\text { Increased } \\
\text { (BSA) }\end{array}$ & ND & More in asthmatics & 137 \\
\hline MWCNT (100 $\mu \mathrm{g} / \mathrm{ml})$ & Calu-3 & Decreased & $\begin{array}{l}\text { Increased } \\
\text { (mannitol) }\end{array}$ & ND & & 138 \\
\hline DEP $(125 \mu \mathrm{g} / \mathrm{ml})$ & 16HBElo- & Decreased & ND & $\begin{array}{l}\text { Slight decrease } \\
\text { membrane occludin }\end{array}$ & & 139 \\
\hline $\begin{array}{l}\text { Ambient } \mathrm{PM}_{10} \\
\left(50 \mu \mathrm{g} / \mathrm{cm}^{2}\right) \text { DEP }\end{array}$ & $\begin{array}{l}\text { A549 Rat } \\
\text { AlvEC }\end{array}$ & Decreased & Increased & $\begin{array}{l}\text { Decreased membrane } \\
\text { occludin by WB } \\
\text { and IF }\end{array}$ & $\begin{array}{l}\text { Possible cytotoxicity; } \\
\text { mitochondrial ROS- } \\
\text { dependent }\end{array}$ & 140 \\
\hline $\begin{array}{l}\text { Ambient PM } \\
(150 \mu \mathrm{g} / \mathrm{ml})\end{array}$ & NHBEC & ND & $\begin{array}{l}\text { Increased } \\
\text { (4 kD dextran) }\end{array}$ & No change in $\beta$-catenin & $\begin{array}{l}\text { Required } 2 \text { applications, } \\
\text { unless septin-2 } \\
\text { knocked-down }\end{array}$ & 16 \\
\hline \multicolumn{7}{|l|}{ Respiratory viruses } \\
\hline $\begin{array}{l}\text { Rhinovirus } \\
\text { (RV39, RV1B, } \\
\text { MOI = 1) }\end{array}$ & $\begin{array}{l}\text { PTEC } \\
\text { 16HBElo- }\end{array}$ & Decreased & $\begin{array}{l}\text { Increased } \\
\text { (FITC-inulin) }\end{array}$ & $\begin{array}{l}\text { ZO-1 dissociation } \\
\text { from AJC }\end{array}$ & $\begin{array}{l}\text { Independent of IL-1 } 1 \beta \text {, } \\
\text { TNF- } \alpha \text {, and IFN- } \gamma \text {; } \\
\text { increased translocation } \\
\text { of apical bacteria; } \\
\text { blocked by DPI }\end{array}$ & 141,142 \\
\hline RSV (A2, 2.5-5) & PBEC A549 & Decreased & ND & $\begin{array}{l}\text { Cytoskeletal } \\
\text { rearrangement }\end{array}$ & Dependent on MAPK & 143 \\
\hline $\begin{array}{l}\mathrm{RSV}(\mathrm{A} 2, \mathrm{MOI}= \\
0.05-1)\end{array}$ & 16HBElo- & Decreased & $\begin{array}{l}\text { Increased } \\
\text { (3 kD dextran) }\end{array}$ & $\begin{array}{l}\text { Expression- } \\
\text { independent } \\
\text { AJC disassembly }\end{array}$ & $\begin{array}{l}\text { Dependent on sustained } \\
\text { PKD activation }\end{array}$ & 108 \\
\hline
\end{tabular}

Definition of abbreviations: AJC, apical junctional complexes; CBE, canine bronchial epithelial cells; DEP, diesel exhaust particles; DPI, diphenylene iodonium; IF, immunofluorescence; MAPK, mitogen-associated protein kinases; MOI, multiplicity of infection; MWCNT, multiwalled carbon nanotubes; ND, not determined; NHBE, normal human bronchial epithelial cells; PKD, protein kinase D; PM, particulate matter; PM ${ }_{10}$, particulate matter < $10 \mu \mathrm{m}$ in diameter; PBEC, primary bronchial epithelial cells; PTEC, primary tracheal epithelial cells; ROS, reactive oxygen species; RSV, respiratory syncytial virus; WB, Western blot. 
Coxsackie virus causes occludin internalization via macropinocytosis, dependent on the Rab GTPases (149).

Pioneering studies by Hershenson and colleagues showed that infection with rhinovirus (RV) leads to epithelial barrier dysfunction in the absence of cell death (141). The apical/basal translocation of bacteria was significantly enhanced after $\mathrm{RV}$ infection, suggesting a mechanism whereby respiratory viral infection predisposes to bacterial superinfection (141). In 16HBElo- cells, RV infection induced expression and activity of NADPH oxidases, and RV-induced barrier dysfunction was inhibited by the NADPH oxidase antagonist diphenylene iodonium (142). We recently showed that RSV also infects $16 \mathrm{HBElo}-$ and primary airway epithelial cells, resulting in sustained decreases in TEER and increased paracellular permeability (108). Barrier disruptive effects of RSV were not associated with cell cytotoxicity but were dependent on sustained activation of PKD. Originally known as $\mathrm{PKC} \mu$, this molecule was renamed because it has different structure and substrate specificity than other PKC family members (150). PKD regulates cell shape and motility in part by controlling actin dynamics, and in support of a role for cytoskeletal remodeling we found that RSV infection induces phosphorylation of the actin binding protein cortactin (108). Additional evidence that cytoskeletal remodeling contributes to RSV-induced barrier dysfunction comes from the studies of Singh and colleagues (143). In a separate study, we found that the double-stranded RNA polyI:C also induced barrier dysfunction and AJC disassembly in a PKD-dependent manner (107). This was not dependent on production of soluble factors but rather involved a cell-intrinsic signaling mechanism dependent in part on toll-like receptor 3 (107). Taken together, these studies suggest that PKD could be more broadly involved in barrier dysfunction caused by respiratory viruses, which will be an interesting area for future studies. Although potentially an evolutionary strategy co-opted by viruses to promote their infectivity, virus-induced epithelial permeability may facilitate the translocation of inhaled aeroallergens and may help explain the association between respiratory viral infection and allergen sensitization in asthma (see below).

\section{Airway Epithelial Barrier Dysfunction in CF and Asthma}

\section{CF}

CFTR protein regulates chloride and sodium movement across the epithelial membrane and is mutated in most cases of CF. In lung epithelium, CFTR facilitates transport of chloride to the apical surface of the epithelium, thus controlling transcellular and paracellular trafficking of ions. In cell lines defective in CFTR, TEER is decreased and permeability to mannitol is increased, due to defective localization and function of TJ in a Rho/Rock-dependent manner (151). In polarized epithelial cells, CFTR is tethered to apical actin cytoskeleton through association with PDZ and ezrin protein, suggesting a mechanism whereby CFTR may regulate other apical membrane proteins, although junctional proteins were not specifically investigated in that report (152). Exposure to cAMP analogs improves barrier function in CFTR-deficient cells (151). In one study, induction of CFTR in CFBE41o(-) cells increased the transepithelial resistance and decreased the paracellular permeability of mannitol (153). These authors suggested that CFTR regulated the depth of TJ at least in part in a tyrosine phosphorylation-dependent manner. Taken together, these studies indicate that normal trafficking and function of CFTR may contribute to airway epithelial tight junction assembly and barrier function, although more research is needed in this area. Another area worthy of study is the role of metalloproteases such as meprin, which are elevated in the lung in CF (154) and have the potential to cleave occludin (155).

Dysfunction of airway barrier function in patients with CF could result in paracellular invasion of pathogenic bacteria, leading to chronic infection and inflammation. One common pathogen in $\mathrm{CF}$ is Pseudomonas aeruginosa, which can colonize airway epithelia and lead to substantial morbidity. Pseudomonas species possess virulence factors that disrupt TJ during bacterial invasion without affecting cell viability, which allows cells to reside in the intercellular space of epithelial cells (156). The ability of epithelial cells to internalize $P$. aeruginosa was correlated with cell polarity and assembly of ZO-1 into junctional complexes but was not affected by cell surface CFTR expression (157). However, the precise role of CFTR in regulating epithelial responses to $P$. aeruginosa is controversial (158). Pretreatment of the bronchial epithelium with the antibiotic azithromycin attenuated the disruptive effect of $P$. aeruginosa on airway epithelial cells and facilitated epithelial recovery independent of antimicrobial activity (159). This was likely due to the fact that azithromycin can augment junctional integrity of airway epithelial cells by promoting the integration of claudin-1, claudin-4, occludin, and JAMA into the AJC (160). These studies highlight the potential for a widely used antibiotic to enhance airway epithelial barrier function and suggest that future studies of barrier restoration in CF may be worthwhile.

\section{Asthma}

Until recently, the evidence for epithelial barrier defects in asthma was circumstantial (161), but several new studies have documented defects in barrier structure and function in airway biopsies or epithelial cells propagated in vitro from subjects with asthma. De Boer and colleagues studied junctional protein expression by immunohistochemistry in bronchial biopsies ( $6-\mu \mathrm{m}$ frozen sections) obtained from subjects with asthma or control subjects (162). Twenty-two subjects with relatively mild asthma who were not on inhaled corticosteroids were enrolled (average age, $30 \mathrm{yr}$; mean $\mathrm{FEV}_{1}, 98 \pm$ $16 \%)$ and compared with 14 nonatopic nonasthmatic control subjects and 25 atopic subjects without asthma (determined by positive skin prick test and negative methacholine).

Airway biopsies were analyzed by immunohistochemistry for intensity of $\alpha$ - and $\beta$-catenin, E-cadherin, and ZO-1 expression using a semiquantitative scoring system in a blinded manner. The main finding was a small but statistically significant reduction in expression of $\alpha$-catenin, E-cadherin, and ZO- 1 in superficial epithelial cells in asthmatic versus control biopsies. A slight reduction in $\alpha$-catenin was also detected in biopsies from nonasthmatic atopic subjects (162). The functional significance of these findings was not determined in this report. Subsequent studies have compared 
primary airway epithelial cells from subjects with asthma versus healthy subjects and reported variable results ranging from no change $(163,164)$ to slight decreases in baseline TEER (165, 166). The numbers of subjects analyzed in these studies was generally small. Fujita and colleagues recently reported that intracellular claudin-1 expression is increased in airway smooth muscle cells in asthma, where it appears to promote proliferation. The molecular mechanisms underlying this unusual effect of claudin-1 require further study (167).

The most comprehensive study to date was reported by Xiao and colleagues in 2011 (168). This important paper analyzed junctional structure and function using different approaches in bronchial biopsies and in bronchial epithelial cells propagated in vitro at ALI. Bronchial biopsies from subjects with asthma with varying asthma severity versus healthy control subjects were embedded in methacrylate, and $2-\mu \mathrm{m}$ sections were analyzed by immunohistochemistry in a semiquantitative and blinded manner. Epithelial brushings were obtained from healthy control subjects and from patients with moderate to severe asthma. Several important observations were contained in this report (168). First, the expression of ZO-1 was significantly reduced in epithelial biopsies (using immunohistochemistry) and in epithelial whole mounts (using confocal imaging), with a trend toward reduced occludin expression. Second, TEER was significantly reduced in epithelial cells after 21 days of culture in vitro and correlated with asthma severity. Cells from subjects with asthma and control subjects responded equally to submersion in tissue culture medium with increased TEER (an expected response indicating barrier tightening), demonstrating that reduced TEER in asthmatic epithelial cells was potentially reversible. Third, reduction in TEER in airway epithelial cells from subjects with asthma was accompanied by increased permeability to 4 - and $20-\mathrm{kD}$ dextrans. Finally, treatment with EGF restored asthmatic epithelial TEER values into the normal range (168). The fact that epithelial cells from subjects with asthma demonstrate defective barrier function after several weeks of culture in vitro indicates that this is a stable property of these cells $(165,166,168)$. The molecular basis for this apparent stability in epithelial barrier dysfunction is unknown, but this may involve changes in cellular composition, epigenetic alterations, or other mechanisms that are resistant to environmental reprogramming.

Very recently, Hackett and colleagues obtained primary bronchial epithelial cells from cadaveric donor lungs from subjects with and without asthma ( $n=6$ each) and obtained bronchial brushings from five subjects with asthma (average age, $42 \mathrm{yr}$; average $\mathrm{FEV}_{1}, 93 \%$ ) and six healthy control subjects (169). After propagation at ALI, confluent monolayers were analyzed by immunofluorescence and confocal microscopy, and TEER was analyzed. The key finding was that cells obtained from asthmatic airways demonstrated reduced expression of E-cadherin, $\beta$-catenin, and caveolin compared with control airways, although baseline TEER was unchanged (169). A causal role for reduced caveolin-1 was inferred because caveolin-1 knockdown in 16 HBElo- cells reduced TEER. The authors speculated that caveolin-1 was required to recruit and stabilize E-cadherin in the AJC, which would be distinct from the barrier-disruptive role for caveolin-1 in junctional endocytosis in the intestine (132-134).

\section{Conclusions}

AJC are complex and dynamic structures and are a key part of epithelial defense mechanisms. Defects in junctional integrity are associated with asthma and CF and may predispose to allergen-induced mucosal inflammation and microbial persistence. Although we have a growing knowledge of the mechanisms involved, the precise molecular basis for airway epithelial junctional dysfunction in disease states requires further study. Most studies to date have been conducted with model epithelia in vitro, but future studies that investigate junctional structure and function in primary cell types in vivo should be especially revealing. Advances in real-time imaging, including multiphoton microscopy, may allow molecular analysis of lung epithelial barrier structures in situ in the near future. The development of noninvasive assays of junctional integrity should accelerate clinical research in this area. Persistence of a dysfunctional barrier in airway epithelial cells from subjects with asthma propagated in vitro indicates that this is a stable cellular phenotype, but there are hints that junctional integrity could be restored. Further delineation of the molecular pathways that promote epithelial barrier function seems particularly important because this will have immediate therapeutic relevance. Perhaps in the not too distant future we will be able to study epithelial barrier function and use targeted therapeutics to restore junctional integrity in the clinic. This would represent an exciting example of translational research in respiratory cell and molecular biology.

Author disclosures are available with the text of this article at www.atsjournals.org.

\section{References}

1. Parker D, Prince A. Innate immunity in the respiratory epithelium. $A m J$ Respir Cell Mol Biol 2011;45:189-201.

2. Niessen CM. Tight junctions/adherens junctions: basic structure and function. J Invest Dermatol 2007;127:2525-2532.

3. Shen L, Weber CR, Raleigh DR, Yu D, Turner JR. Tight junction pore and leak pathways: a dynamic duo. Annu Rev Physiol 2011;73:283-309.

4. Matter K, Balda MS. Signalling to and from tight junctions. Nat Rev Mol Cell Biol 2003;4:225-236.

5. McCrea PD, Gu D, Balda MS. Junctional music that the nucleus hears: cell-cell contact signaling and the modulation of gene activity. Cold Spring Harb Perspect Biol 2009;1:a002923.
6. Finigan JH, Downey GP, Kern JA. Human epidermal growth factor receptor signaling in acute lung injury. Am J Respir Cell Mol Biol 2012; 47:395-404.

7. Frank JA. Claudins and alveolar epithelial barrier function in the lung Ann N Y Acad Sci 2012;1257:175-183.

8. Koval M. Claudin heterogeneity and control of lung tight junctions. Annu Rev Physiol 2013;75:551-567.

9. Godfrey RW, Severs NJ, Jeffery PK. Freeze-fracture morphology and quantification of human bronchial epithelial tight junctions. Am J Respir Cell Mol Biol 1992;6:453-458.

10. Godfrey RW, Severs NJ, Jeffery PK. Structural alterations of airway epithelial tight junctions in cystic fibrosis: comparison of transplant and postmortem tissue. Am J Respir Cell Mol Biol 1993; 9:148-156. 
11. Strengert M, Knaus UG. Analysis of epithelial barrier integrity in polarized lung epithelial cells. Methods Mol Biol 2011;763:195-206.

12. You Y, Richer EJ, Huang T, Brody SL. Growth and differentiation of mouse tracheal epithelial cells: selection of a proliferative population. Am J Physiol Lung Cell Mol Physiol 2002;283:L1315-L1321.

13. Sidhaye VK, Schweitzer KS, Caterina MJ, Shimoda L, King LS. Shear stress regulates aquaporin- 5 and airway epithelial barrier function. Proc Natl Acad Sci USA 2008;105:3345-3350.

14. Vermeer PD, Einwalter LA, Moninger TO, Rokhlina T, Kern JA, Zabner J, Welsh MJ. Segregation of receptor and ligand regulates activation of epithelial growth factor receptor. Nature 2003;422:322-326.

15. Humlicek AL, Manzel LJ, Chin CL, Shi L, Excoffon KJ, Winter MC, Shasby DM, Look DC. Paracellular permeability restricts airway epithelial responses to selectively allow activation by mediators at the basolateral surface. J Immunol 2007;178:6395-6403.

16. Sidhaye VK, Chau E, Breysse PN, King LS. Septin-2 mediates airway epithelial barrier function in physiologic and pathologic conditions. Am J Respir Cell Mol Biol 2011;45:120-126.

17. Schneeberger EE, Lynch RD. The tight junction: a multifunctional complex. Am J Physiol Cell Physiol 2004;286:C1213-C1228.

18. Stevenson BR, Anderson JM, Goodenough DA, Mooseker MS. Tight junction structure and ZO-1 content are identical in two strains of Madin-Darby canine kidney cells which differ in transepithelial resistance. J Cell Biol 1988;107:2401-2408.

19. Balda MS, Whitney JA, Flores C, González S, Cereijido M, Matter K. Functional dissociation of paracellular permeability and transepithelial electrical resistance and disruption of the apicalbasolateral intramembrane diffusion barrier by expression of a mutant tight junction membrane protein. J Cell Biol 1996;134: 1031-1049.

20. McCarthy KM, Francis SA, McCormack JM, Lai J, Rogers RA, Skare IB, Lynch RD, Schneeberger EE. Inducible expression of claudin-1-myc but not occludin-VSV-G results in aberrant tight junction strand formation in MDCK cells. J Cell Sci 2000;113:3387-3398.

21. Benais-Pont G, Punn A, Flores-Maldonado C, Eckert J, Raposo G, Fleming TP, Cereijido M, Balda MS, Matter K. Identification of a tight junction-associated guanine nucleotide exchange factor that activates Rho and regulates paracellular permeability. J Cell Biol 2003;160:729-740.

22. Takeichi M. Shoichiro Tsukita: a life exploring the molecular architecture of the tight junction. J Cell Biol 2006;172:321-323.

23. Schulzke JD, Fromm M. Tight junctions: molecular structure meets function. Ann N Y Acad Sci 2009;1165:1-6.

24. Niessen CM, Gottardi CJ. Molecular components of the adherens junction. Biochim Biophys Acta 2008;1778:562-571.

25. Furuse M, Fujita K, Hiiragi T, Fujimoto K, Tsukita S. Claudin-1 and -2: novel integral membrane proteins localizing at tight junctions with no sequence similarity to occludin. J Cell Biol 1998;141:1539-1550.

26. Krause G, Winkler L, Mueller SL, Haseloff RF, Piontek J, Blasig IE. Structure and function of claudins. Biochim Biophys Acta 2008;1778: 631-645.

27. Angelow S, Ahlstrom R, Yu AS. Biology of claudins. Am J Physiol Renal Physiol 2008;295:F867-F876.

28. Colegio OR, Van Itallie C, Rahner C, Anderson JM. Claudin extracellular domains determine paracellular charge selectivity and resistance but not tight junction fibril architecture. Am J Physiol Cell Physiol 2003; 284:C1346-C1354.

29. Rosen MJ, Chaturvedi R, Washington MK, Kuhnhein LA, Moore PD, Coggeshall SS, McDonough EM, Weitkamp JH, Singh AB, Coburn LA, et al. STAT6 deficiency ameliorates severity of oxazolone colitis by decreasing expression of claudin-2 and Th2-inducing cytokines. $J$ Immunol 2013;190:1849-1858.

30. Saatian B, et al. Interleukin-4 and interleukin-13 cause barrier dysfunction in human airway epithelial cells. Tissue Barriers 2013;1: e243333-e243335.

31. Soini Y. Claudins in lung diseases. Respir Res 2011;12:70.

32. Coyne CB, Gambling TM, Boucher RC, Carson JL, Johnson LG. Role of claudin interactions in airway tight junctional permeability. $A m \mathrm{~J}$ Physiol Lung Cell Mol Physiol 2003;285:L1166-L1178.
33. LaFemina MJ, Rokkam D, Chandrasena A, Pan J, Bajaj A, Johnson $M$, Frank JA. Keratinocyte growth factor enhances barrier function without altering claudin expression in primary alveolar epithelial cells. Am J Physiol Lung Cell Mol Physiol 2010;299: L724-L734.

34. Ohta H, Chiba S, Ebina M, Furuse M, Nukiwa T. Altered expression of tight junction molecules in alveolar septa in lung injury and fibrosis. Am J Physiol Lung Cell Mol Physiol 2012;302:L193-L205.

35. Kaarteenaho-Wiik R, Soini Y. Claudin-1, $-2,-3,-4,-5$, and -7 in usual interstitial pneumonia and sarcoidosis. J Histochem Cytochem 2009; 57:187-195.

36. Mitchell LA, Overgaard CE, Ward C, Margulies SS, Koval M. Differential effects of claudin-3 and claudin-4 on alveolar epithelial barrier function. Am J Physiol Lung Cell Mol Physiol 2011;301:L40-L49.

37. Koval M. Claudin heterogeneity and control of lung tight junctions. Annu Rev Physiol 2013;75:551-567.

38. Sonoda N, Furuse M, Sasaki H, Yonemura S, Katahira J, Horiguchi Y, Tsukita S. Clostridium perfringens enterotoxin fragment removes specific claudins from tight junction strands: evidence for direct involvement of claudins in tight junction barrier. J Cell Biol 1999;147: 195-204.

39. Takahashi A, Kondoh M, Suzuki H, Yagi K. Claudin as a target for drug development. Curr Med Chem 2011;18:1861-1865.

40. Wang G, Zabner J, Deering C, Launspach J, Shao J, Bodner M, Jolly DJ, Davidson BL, McCray PB Jr. Increasing epithelial junction permeability enhances gene transfer to airway epithelia in vivo. $A m \mathrm{~J}$ Respir Cell Mol Biol 2000;22:129-138.

41. Coyne CB, Vanhook MK, Gambling TM, Carson JL, Boucher RC, Johnson LG. Regulation of airway tight junctions by proinflammatory cytokines. Mol Biol Cell 2002;13:3218-3234.

42. Nitta T, Hata M, Gotoh S, Seo Y, Sasaki H, Hashimoto N, Furuse M, Tsukita S. Size-selective loosening of the blood-brain barrier in claudin-5-deficient mice. J Cell Biol 2003;161:653-660.

43. Armstrong SM, Wang C, Tigdi J, Si X, Dumpit C, Charles S, Gamage A Moraes TJ, Lee WL. Influenza infects lung microvascular endothelium leading to microvascular leak: role of apoptosis and claudin-5. PLoS ONE 2012;7:e47323.

44. Pfeiffer F, Kumar V, Butz S, Vestweber D, Imhof BA, Stein JV, Engelhardt B. Distinct molecular composition of blood and lymphatic vascular endothelial cell junctions establishes specific functional barriers within the peripheral lymph node. Eur J Immunol 2008;38: 2142-2155.

45. LaFemina MJ, Sweerus K, Gordon ED, Lachowicz-Scroggins ME, Bentley T, Sutherland K, Fahy JV, Frank JA. in American Thoracic Society Abstract \#A3562 (Philadelphia, 2012).

46. Chang EH, Pezzulo AA, Zabner J. Do cell junction protein mutations cause an airway phenotype in mice or humans? Am J Respir Cell Mol Biol 2011;45:202-220.

47. Furuse M, Hata M, Furuse K, Yoshida Y, Haratake A, Sugitani Y, Noda T, Kubo A, Tsukita S. Claudin-based tight junctions are crucial for the mammalian epidermal barrier: a lesson from claudin-1-deficient mice. J Cell Biol 2002;156:1099-1111.

48. Muto S, Hata M, Taniguchi J, Tsuruoka S, Moriwaki K, Saitou M, Furuse K, Sasaki H, Fujimura A, Imai M, et al. Claudin-2-deficient mice are defective in the leaky and cation-selective paracellular permeability properties of renal proximal tubules. Proc Natl Acad Sci USA 2010;107:8011-8016.

49. Fujita H, Hamazaki Y, Noda Y, Oshima M, Minato N. Claudin-4 deficiency results in urothelial hyperplasia and lethal hydronephrosis. PLOS ONE 2012;7:e52272.

50. Ben-Yosef T, Belyantseva IA, Saunders TL, Hughes ED, Kawamoto K, Van Itallie CM, Beyer LA, Halsey K, Gardner DJ, Wilcox ER, et al. Claudin 14 knockout mice, a model for autosomal recessive deafness DFNB29, are deaf due to cochlear hair cell degeneration. Hum Mol Genet 2003;12:2049-2061.

51. Tamura A, Kitano Y, Hata M, Katsuno T, Moriwaki K, Sasaki H, Hayash $\mathrm{H}$, Suzuki $\mathrm{Y}$, Noda T, Furuse M, et al. Megaintestine in claudin-15deficient mice. Gastroenterology 2008;134:523-534.

52. Tamura A, Hayashi H, Imasato M, Yamazaki $Y$, Hagiwara A, Wada M, Noda T, Watanabe M, Suzuki Y, Tsukita S. Loss of claudin-15, but not claudin-2, causes $\mathrm{Na}+$ deficiency and glucose malabsorption in mouse small intestine. Gastroenterology 2011;140:913-923. 
53. Saitou M, Furuse M, Sasaki H, Schulzke JD, Fromm M, Takano H, Noda T, Tsukita S. Complex phenotype of mice lacking occludin, a component of tight junction strands. Mol Biol Cell 2000;11: 4131-4142.

54. Edelblum KL, Shen L, Weber CR, Marchiando AM, Clay BS, Wang $Y$, Prinz I, Malissen B, Sperling AI, Turner JR. Dynamic migration of $\gamma \delta$ intraepithelial lymphocytes requires occludin. Proc Natl Acad Sci USA 2012;109:7097-7102.

55. Katsuno T, Umeda K, Matsui T, Hata M, Tamura A, Itoh M, Takeuchi K, Fujimori T, Nabeshima Y, Noda T, et al. Deficiency of zonula occludens- 1 causes embryonic lethal phenotype associated with defected yolk sac angiogenesis and apoptosis of embryonic cells. Mol Biol Cell 2008;19:2465-2475.

56. Xu J, Kausalya PJ, Phua DC, Ali SM, Hossain Z, Hunziker W. Early embryonic lethality of mice lacking ZO-2, but not ZO-3, reveals critical and nonredundant roles for individual zonula occludens proteins in mammalian development. Mol Cell Biol 2008;28: 1669-1678.

57. Xu J, Anuar F, Ali SM, Ng MY, Phua DC, Hunziker W. Zona occludens-2 is critical for blood-testis barrier integrity and male fertility. Mol Biol Cell 2009;20:4268-4277.

58. Adachi M, Inoko A, Hata M, Furuse K, Umeda K, Itoh M, Tsukita S. Normal establishment of epithelial tight junctions in mice and cultured cells lacking expression of ZO-3, a tight-junction MAGUK protein. Mol Cell Biol 2006;26:9003-9015.

59. Pazirandeh A, Sultana T, Mirza M, Rozell B, Hultenby K, Wallis K, Vennström B, Davis B, Arner A, Heuchel R, et al. Multiple phenotypes in adult mice following inactivation of the Coxsackievirus and Adenovirus Receptor (Car) gene. PLoS ONE 2011;6:e20203.

60. Lakshmi SP, Reddy AT, Naik MU, Naik UP, Reddy RC. Effects of JAMA deficiency or blocking antibodies on neutrophil migration and lung injury in a murine model of ALI. Am J Physiol Lung Cell Mol Physiol 2012;303:L758-L766.

61. Monteiro AC, Sumagin R, Rankin CR, Leoni G, Mina MJ, Reiter DM, Stehle T, Dermody TS, Schaefer SA, Hall RA, et al. JAM-A associates with ZO-2, afadin, and PDZ-GEF1 to activate Rap2c and regulate epithelial barrier function. Mol Biol Cell 2013;24:2849-2860.

62. Hadj-Rabia S, Baala L, Vabres P, Hamel-Teillac D, Jacquemin E, Fabre M, Lyonnet S, De Prost Y, Munnich A, Hadchouel M, et al. Claudin-1 gene mutations in neonatal sclerosing cholangitis associated with ichthyosis: a tight junction disease. Gastroenterology 2004;127: 1386-1390.

63. Simon DB, Lu Y, Choate KA, Velazquez H, Al-Sabban E, Praga M, Casari G, Bettinelli A, Colussi G, Rodriguez-Soriano J, et al. Paracellin-1, a renal tight junction protein required for paracellular Mg2+ resorption. Science 1999;285:103-106.

64. Wilcox ER, Burton QL, Naz S, Riazuddin S, Smith TN, Ploplis B, Belyantseva I, Ben-Yosef T, Liburd NA, Morell RJ, et al. Mutations in the gene encoding tight junction claudin-14 cause autosomal recessive deafness DFNB29. Cell 2001;104:165-172.

65. De Benedetto A, Rafaels NM, McGirt LY, Ivanov Al, Georas SN, Cheadle C, Berger AE, Zhang K, Vidyasagar S, Yoshida T, et al. Tight junction defects in patients with atopic dermatitis. J Allergy Clin Immunol 2011;127:773-786, e1-7.

66. De Benedetto A, Kubo A, Beck LA. Skin barrier disruption: a requirement for allergen sensitization? J Invest Dermatol 2012;132: 949-963.

67. Furuse M, Hirase T, Itoh M, Nagafuchi A, Yonemura S, Tsukita S, Tsukita S. Occludin: a novel integral membrane protein localizing at tight junctions. J Cell Biol 1993;123:1777-1788.

68. Cummins PM. Occludin: one protein, many forms. Mol Cell Biol 2012; 32:242-250.

69. Andreeva AY, Krause E, Müller EC, Blasig IE, Utepbergenov DI. Protein kinase $C$ regulates the phosphorylation and cellular localization of occludin. J Biol Chem 2001;276:38480-38486.

70. Fanning AS, Jameson BJ, Jesaitis LA, Anderson JM. The tight junction protein ZO-1 establishes a link between the transmembrane protein occludin and the actin cytoskeleton. J Biol Chem 1998;273: 29745-29753.
71. Van Itallie CM, Fanning AS, Bridges A, Anderson JM. ZO-1 stabilizes the tight junction solute barrier through coupling to the perijunctional cytoskeleton. Mol Biol Cell 2009;20:3930-3940.

72. Elias BC, Suzuki T, Seth A, Giorgianni F, Kale G, Shen L, Turner JR, Naren A, Desiderio DM, Rao R. Phosphorylation of Tyr-398 and Tyr402 in occludin prevents its interaction with ZO-1 and destabilizes its assembly at the tight junctions. J Biol Chem 2009;284:1559-1569.

73. Li Y, Fanning AS, Anderson JM, Lavie A. Structure of the conserved cytoplasmic C-terminal domain of occludin: identification of the ZO1 binding surface. $J$ Mol Biol 2005;352:151-164.

74. Shen L, Weber CR, Turner JR. The tight junction protein complex undergoes rapid and continuous molecular remodeling at steady state. J Cell Biol 2008;181:683-695.

75. Furuse M, Sasaki H, Fujimoto K, Tsukita S. A single gene product, claudin-1 or -2 , reconstitutes tight junction strands and recruits occludin in fibroblasts. J Cell Biol 1998;143:391-401.

76. Tsukita S, Furuse M, Itoh M. Multifunctional strands in tight junctions. Nat Rev Mol Cell Biol 2001;2:285-293.

77. Van Itallie CM, Fanning AS, Holmes J, Anderson JM. Occludin is required for cytokine-induced regulation of tight junction barriers. J Cell Sci 2010;123:2844-2852.

78. Balda MS, Flores-Maldonado C, Cereijido M, Matter K. Multiple domains of occludin are involved in the regulation of paracellular permeability. J Cell Biochem 2000;78:85-96.

79. Al-Sadi R, Khatib K, Guo S, Ye D, Youssef M, Ma T. Occludin regulates macromolecule flux across the intestinal epithelial tight junction barrier. Am J Physiol Gastrointest Liver Physiol 2011;300:G1054-G1064.

80. Everett RS, Vanhook MK, Barozzi N, Toth I, Johnson LG. Specific modulation of airway epithelial tight junctions by apical application of an occludin peptide. Mol Pharmacol 2006;69:492-500.

81. Tavelin S, Hashimoto K, Malkinson J, Lazorova L, Toth I, Artursson P. A new principle for tight junction modulation based on occludin peptides. Mol Pharmacol 2003;64:1530-1540.

82. Olson N, Hristova M, Heintz NH, Lounsbury KM, van der Vliet A. Activation of hypoxia-inducible factor- 1 protects airway epithelium against oxidant-induced barrier dysfunction. Am J Physiol Lung Cell Mol Physiol 2011;301:L993-L1002.

83. Blasig IE, Bellmann C, Cording J, Del Vecchio G, Zwanziger D, Huber O, Haseloff RF. Occludin protein family: oxidative stress and reducing conditions. Antioxid Redox Signal 2011;15:1195-1219.

84. Furuta GT, Turner JR, Taylor CT, Hershberg RM, Comerford K, Narravula S, Podolsky DK, Colgan SP. Hypoxia-inducible factor 1dependent induction of intestinal trefoil factor protects barrier function during hypoxia. J Exp Med 2001;193:1027-1034.

85. Karhausen J, Furuta GT, Tomaszewski JE, Johnson RS, Colgan SP, Haase VH. Epithelial hypoxia-inducible factor-1 is protective in murine experimental colitis. J Clin Invest 2004;114:1098-1106.

86. Schulzke JD, Gitter AH, Mankertz J, Spiegel S, Seidler U, Amasheh S, Saitou M, Tsukita S, Fromm M. Epithelial transport and barrier function in occludin-deficient mice. Biochim Biophys Acta 2005;1669:34-42.

87. Dorner M, Horwitz JA, Donovan BM, Labitt RN, Budell WC, Friling T, Vogt A, Catanese MT, Satoh T, Kawai T, et al. Completion of the entire hepatitis $C$ virus life cycle in genetically humanized mice. Nature 2013;501:237-241.

88. Liu S, Yang W, Shen L, Turner JR, Coyne CB, Wang T. Tight junction proteins claudin-1 and occludin control hepatitis $C$ virus entry and are downregulated during infection to prevent superinfection. $J$ Virol 2009;83:2011-2014.

89. Ploss A, Evans MJ, Gaysinskaya VA, Panis M, You H, de Jong YP, Rice $\mathrm{CM}$. Human occludin is a hepatitis $C$ virus entry factor required for infection of mouse cells. Nature 2009;457:882-886.

90. Yu AS, McCarthy KM, Francis SA, McCormack JM, Lai J, Rogers RA Lynch RD, Schneeberger EE. Knockdown of occludin expression leads to diverse phenotypic alterations in epithelial cells. Am J Physiol Cell Physiol 2005;288:C1231-C1241.

91. Huber D, Balda MS, Matter K. Occludin modulates transepithelial migration of neutrophils. J Biol Chem 2000;275:5773-5778.

92. Stevenson BR, Siliciano JD, Mooseker MS, Goodenough DA. Identification of ZO-1: a high molecular weight polypeptide associated with the tight junction (zonula occludens) in a variety of epithelia. J Cell Biol 1986;103:755-766. 
93. González-Mariscal L, Betanzos A, Avila-Flores A. MAGUK proteins: structure and role in the tight junction. Semin Cell Dev Biol 2000;11:315-324.

94. Fanning AS, Anderson JM. Zonula occludens-1 and -2 are cytosolic scaffolds that regulate the assembly of cellular junctions. Ann NY Acad Sci 2009;1165:113-120.

95. Jesaitis LA, Goodenough DA. Molecular characterization and tissue distribution of ZO-2, a tight junction protein homologous to ZO-1 and the Drosophila discs-large tumor suppressor protein. J Cell Biol 1994;124:949-961.

96. Haskins J, Gu L, Wittchen ES, Hibbard J, Stevenson BR. ZO-3, a novel member of the MAGUK protein family found at the tight junction, interacts with ZO-1 and occludin. J Cell Biol 1998;141:199-208.

97. Lye MF, Fanning AS, Su Y, Anderson JM, Lavie A. Insights into regulated ligand binding sites from the structure of ZO-1 Src homology 3guanylate kinase module. J Biol Chem 2010;285:13907-13917.

98. Pan L, Chen J, Yu J, Yu H, Zhang M. The structure of the PDZ3-SH3GuK tandem of ZO-1 protein suggests a supramodular organization of the membrane-associated guanylate kinase (MAGUK) family scaffold protein core. J Biol Chem 2011;286:40069-40074.

99. Tash BR, Bewley MC, Russo M, Keil JM, Griffin KA, Sundstrom JM, Antonetti DA, Tian F, Flanagan JM. The occludin and ZO-1 complex, defined by small angle $X$-ray scattering and NMR, has implications for modulating tight junction permeability. Proc Natl Acad Sci USA 2012;109:10855-10860.

100. Rodgers LS, Beam MT, Anderson JM, Fanning AS. Epithelial barrier assembly requires coordinated activity of multiple domains of the tight junction protein ZO-1. J Cell Sci 2013;126:1565-1575.

101. González-Mariscal L, Quirós M, Díaz-Coránguez M. ZO proteins and redox-dependent processes. Antioxid Redox Signal 2011;15: 1235-1253.

102. Tapia R, Huerta M, Islas S, Avila-Flores A, Lopez-Bayghen E, Weiske J, Huber O, González-Mariscal L. Zona occludens-2 inhibits cyclin D1 expression and cell proliferation and exhibits changes in localization along the cell cycle. Mol Biol Cell 2009;20:1102-1117.

103. Bauer H, Zweimueller-Mayer J, Steinbacher P, Lametschwandtner A, Bauer HC. The dual role of zonula occludens (ZO) proteins. $J$ Biomed Biotechnol 2010;2010:402593.

104. Betanzos A, Huerta M, Lopez-Bayghen E, Azuara E, Amerena J, González-Mariscal L. The tight junction protein ZO-2 associates with Jun, Fos and C/EBP transcription factors in epithelial cells. Exp Cell Res 2004;292:51-66.

105. Umeda K, Ikenouchi J, Katahira-Tayama S, Furuse K, Sasaki H, Nakayama M, Matsui T, Tsukita S, Furuse M, Tsukita S. ZO-1 and ZO-2 independently determine where claudins are polymerized in tight-junction strand formation. Cell 2006;126:741-754.

106. Fanning AS, Van Itallie CM, Anderson JM. Zonula occludens-1 and -2 regulate apical cell structure and the zonula adherens cytoskeleton in polarized epithelia. Mol Biol Cell 2012;23:577-590.

107. Rezaee, F. et al. Polyinosinic:polycytidylic acid induces protein kinase D-dependent disassembly of apical junctions and barrier dysfunction in airway epithelial cells. J Allergy Clin Immunol 2011; 128:1216-1224, e11.

108. Rezaee F, DeSando SA, Ivanov Al, Chapman TJ, Knowlden SA, Beck LA, Georas SN. Sustained protein kinase D activation mediates respiratory syncytial virus-induced airway barrier disruption. $J$ Virol 2013;87:11088-11095.

109. Grumbach Y, Quynh NV, Chiron R, Urbach V. LXA4 stimulates ZO-1 expression and transepithelial electrical resistance in human airway epithelial (16HBE14o-) cells. Am J Physiol Lung Cell Mol Physiol 2009;296:L101-L108.

110. Ikenouchi J, Furuse M, Furuse K, Sasaki H, Tsukita S, Tsukita S. Tricellulin constitutes a novel barrier at tricellular contacts of epithelial cells. J Cell Biol 2005;171:939-945.

111. Riazuddin S, Ahmed ZM, Fanning AS, Lagziel A, Kitajiri S, Ramzan K, Khan SN, Chattaraj P, Friedman PL, Anderson JM, et al. Tricellulin is a tight-junction protein necessary for hearing. Am J Hum Genet 2006;79:1040-1051.

112. Ohkuni T, Kojima T, Ogasawara N, Masaki T, Ninomiya T, Kikuchi S, Go M, Takano K, Himi T, Sawada N. Expression and localization of tricellulin in human nasal epithelial cells in vivo and in vitro. Med Mol Morphol 2009;42:204-211.
113. Mariano C, Silva SL, Pereira P, Fernandes A, Brites D, Brito MA. Evidence of tricellulin expression by immune cells, particularly microglia. Biochem Biophys Res Commun 2011;409:799-802.

114. Timmann C, Thye T, Vens M, Evans J, May J, Ehmen C, Sievertsen J, Muntau B, Ruge G, Loag W, et al. Genome-wide association study indicates two novel resistance loci for severe malaria. Nature 2012;489:443-446.

115. Excoffon KJ, Guglielmi KM, Wetzel JD, Gansemer ND, Campbell JA, Dermody TS, Zabner J. Reovirus preferentially infects the basolateral surface and is released from the apical surface of polarized human respiratory epithelial cells. J Infect Dis 2008;197: 1189-1197.

116. Excoffon KJ, Gansemer ND, Mobily ME, Karp PH, Parekh KR, Zabner J. Isoform-specific regulation and localization of the coxsackie and adenovirus receptor in human airway epithelia. PLoS ONE 2010;5:e9909.

117. Walters RW, Freimuth P, Moninger TO, Ganske I, Zabner J, Welsh MJ. Adenovirus fiber disrupts CAR-mediated intercellular adhesion allowing virus escape. Cell 2002;110:789-799.

118. Verdino P, Witherden DA, Havran WL, Wilson IA. The molecular interaction of CAR and JAML recruits the central cell signal transducer PI3K. Science 2010;329:1210-1214.

119. Witherden DA, Verdino P, Rieder SE, Garijo O, Mills RE, Teyton L, Fischer WH, Wilson IA, Havran WL. The junctional adhesion molecule JAML is a costimulatory receptor for epithelial gammadelta T cell activation. Science 2010;329:1205-1210.

120. Zemke AC, Teisanu RM, Giangreco A, Drake JA, Brockway BL, Reynolds SD, Stripp BR. beta-Catenin is not necessary for maintenance or repair of the bronchiolar epithelium. Am J Respir Cell Mol Biol 2009;41:535-543.

121. Zemans RL, McClendon J, Aschner Y, Briones N, Young SK, Lau LF Kahn M, Downey GP. Role of $\beta$-catenin-regulated CCN matricellular proteins in epithelial repair after inflammatory lung injury. Am J Physiol Lung Cell Mol Physiol 2013;304:L415-L427.

122. Smalley-Freed WG, Efimov A, Burnett PE, Short SP, Davis MA, Gumucio DL, Washington MK, Coffey RJ, Reynolds AB. p120catenin is essential for maintenance of barrier function and intestinal homeostasis in mice. J Clin Invest 2010;120:1824-1835.

123. Assémat $E$, Bazellières $E$, Pallesi-Pocachard E, Le Bivic A, MasseyHarroche D. Polarity complex proteins. Biochim Biophys Acta 2008; 1778:614-630.

124. Wang Q, Margolis B. Apical junctional complexes and cell polarity. Kidney Int 2007;72:1448-1458.

125. Yates LL, Dean CH. Planar polarity: a new player in both lung development and disease. Organogenesis 2011;7:209-216.

126. Yates LL, Schnatwinkel C, Hazelwood L, Chessum L, Paudyal A, Hilton H, Romero MR, Wilde J, Bogani D, Sanderson J, et al. Scribble is required for normal epithelial cell-cell contacts and lumen morphogenesis in the mammalian lung. Dev Biol 2013;373: 267-280.

127. Whiteman EL, Fan S, Harder JL, Walton KD, Liu CJ, Soofi A, Fogg VC, Hershenson MB, Dressler GR, Deutsch GH, et al. Crumbs3 is essential for proper epithelial development and viability. Mol Cell Biol 2014;34:43-56.

128. Borok Z, Whitsett JA, Bitterman PB, Thannickal VJ, Kotton DN, Reynolds SD, Krasnow MA, Bianchi DW, Morrisey EE, Hogan BL, et al. Cell plasticity in lung injury and repair: report from an NHLBI workshop, April 19-20, 2010. Proc Am Thorac Soc 2010;8: 215-222.

129. Beers MF, Morrisey EE. The three R's of lung health and disease: repair, remodeling, and regeneration. J Clin Invest 2011;121: 2065-2073.

130. Ivanov Al, Nusrat A, Parkos CA. Endocytosis of the apical junctional complex: mechanisms and possible roles in regulation of epithelial barriers. Bioessays 2005;27:356-365.

131. Ivanov Al, Parkos CA, Nusrat A. Cytoskeletal regulation of epithelial barrier function during inflammation. Am J Pathol 2010;177:512-524.

132. Clayburgh DR, Barrett TA, Tang Y, Meddings JB, Van Eldik LJ, Watterson DM, Clarke LL, Mrsny RJ, Turner JR. Epithelial myosin light chain kinase-dependent barrier dysfunction mediates $T$ cell activation-induced diarrhea in vivo. J Clin Invest 2005;115: 2702-2715 
133. Marchiando AM, Shen L, Graham WV, Weber CR, Schwarz BT, Austin JR II, Raleigh DR, Guan Y, Watson AJ, Montrose MH, et al. Caveolin1-dependent occludin endocytosis is required for TNF-induced tight junction regulation in vivo. J Cell Biol 2010;189:111-126.

134. Yu D, Marchiando AM, Weber CR, Raleigh DR, Wang Y, Shen L, Turner JR. MLCK-dependent exchange and actin binding regiondependent anchoring of ZO-1 regulate tight junction barrier function. Proc Natl Acad Sci USA 2010;107:8237-8241.

135. Schamberger AC, Mise N, Jia J, Genoyer E, Yildirim AO, Meiners S, Eickelberg O. Cigarette smoke-induced disruption of bronchial epithelial tight junctions is prevented by transforming growth factorbeta. Am J Respir Cell Mol Biol (In press)

136. Yu XY, Takahashi N, Croxton TL, Spannhake EW. Modulation of bronchial epithelial cell barrier function by in vitro ozone exposure. Environ Health Perspect 1994;102:1068-1072.

137. Bayram H, Rusznak C, Khair OA, Sapsford RJ, Abdelaziz MM. Effect of ozone and nitrogen dioxide on the permeability of bronchial epithelial cell cultures of non-asthmatic and asthmatic subjects. Clin Exp Allergy 2002;32:1285-1292.

138. Rotoli BM, Bussolati O, Bianchi MG, Barilli A, Balasubramanian C, Bellucci S, Bergamaschi E. Non-functionalized multi-walled carbon nanotubes alter the paracellular permeability of human airway epithelial cells. Toxicol Lett 2008;178:95-102.

139. Lehmann AD, Blank F, Baum O, Gehr P, Rothen-Rutishauser BM. Diesel exhaust particles modulate the tight junction protein occludin in lung cells in vitro. Part Fibre Toxicol 2009;6:26.

140. Caraballo JC, Yshii C, Westphal W, Moninger T, Comellas AP. Ambient particulate matter affects occludin distribution and increases alveolar transepithelial electrical conductance. Respirology 2011;16:340-349.

141. Sajjan U, Wang Q, Zhao Y, Gruenert DC, Hershenson MB. Rhinovirus disrupts the barrier function of polarized airway epithelial cells. Am J Respir Crit Care Med 2008;178:1271-1281.

142. Comstock AT, Ganesan S, Chattoraj A, Faris AN, Margolis BL, Hershenson MB, Sajjan US. Rhinovirus-induced barrier dysfunction in polarized airway epithelial cells is mediated by NADPH oxidase 1 . $J$ Virol 2011;85:6795-6808.

143. Singh D, McCann KL, Imani F. MAPK and heat shock protein 27 activation are associated with respiratory syncytial virus induction of human bronchial epithelial monolayer disruption. Am J Physiol Lung Cell Mol Physiol 2007;293:L436-L445.

144. Thevenot PT, Saravia J, Jin N, Giaimo JD, Chustz RE, Mahne S, Kelley MA, Hebert VY, Dellinger B, Dugas TR, et al. Radical-containing ultrafine particulate matter initiates epithelial-to-mesenchymal transitions in airway epithelial cells. Am J Respir Cell Mol Biol 2013;48:188-197.

145. Bräuner EV, Mortensen J, Møller P, Bernard A, Vinzents $P$, Wåhlin $P$, Glasius M, Loft S. Effects of ambient air particulate exposure on bloodgas barrier permeability and lung function. Inhal Toxicol 2009;21:38-47.

146. Bergelson JM, Cunningham JA, Droguett G, Kurt-Jones EA, Krithivas A, Hong JS, Horwitz MS, Crowell RL, Finberg RW. Isolation of a common receptor for Coxsackie B viruses and adenoviruses 2 and 5. Science 1997;275:1320-1323.

147. Barton ES, Forrest JC, Connolly JL, Chappell JD, Liu Y, Schnell FJ, Nusrat A, Parkos CA, Dermody TS. Junction adhesion molecule is a receptor for reovirus. Cell 2001;104:441-451.

148. Coyne CB, Bergelson JM. Virus-induced Abl and Fyn kinase signals permit coxsackievirus entry through epithelial tight junctions. Cell 2006;124:119-131.

149. Coyne CB, Shen L, Turner JR, Bergelson JM. Coxsackievirus entry across epithelial tight junctions requires occludin and the small GTPases Rab34 and Rab5. Cell Host Microbe 2007;2:181-192.

150. Valverde AM, Sinnett-Smith J, Van Lint J, Rozengurt E. Molecular cloning and characterization of protein kinase $\mathrm{D}$ : a target for diacylglycerol and phorbol esters with a distinctive catalytic domain. Proc Natl Acad Sci USA 1994:91:8572-8576.

151. Weiser N, Molenda N, Urbanova K, Bähler M, Pieper U, Oberleithner $\mathrm{H}$, Schillers $\mathrm{H}$. Paracellular permeability of bronchial epithelium is controlled by CFTR. Cell Physiol Biochem 2011;28:289-296.
152. Short DB, Trotter KW, Reczek D, Kreda SM, Bretscher A, Boucher RC, Stutts MJ, Milgram SL. An apical PDZ protein anchors the cystic fibrosis transmembrane conductance regulator to the cytoskeleton. J Biol Chem 1998;273:19797-19801.

153. LeSimple P, Liao J, Robert R, Gruenert DC, Hanrahan JW. Cystic fibrosis transmembrane conductance regulator trafficking modulates the barrier function of airway epithelial cell monolayers. J Physiol 2010;588:1195-1209.

154. Bergin DA, Greene CM, Sterchi EE, Kenna C, Geraghty P, Belaaouaj A, Taggart CC, O'Neill SJ, McElvaney NG. Activation of the epidermal growth factor receptor (EGFR) by a novel metalloprotease pathway. J Biol Chem 2008;283:31736-31744.

155. Bao J, Yura RE, Matters GL, Bradley SG, Shi P, Tian F, Bond JS. Meprin A impairs epithelial barrier function, enhances monocyte migration, and cleaves the tight junction protein occludin. Am J Physiol Renal Physiol 2013;305:F714-F726.

156. Zulianello L, Canard C, Köhler T, Caille D, Lacroix JS, Meda P. Rhamnolipids are virulence factors that promote early infiltration of primary human airway epithelia by Pseudomonas aeruginosa. Infect Immun 2006;74:3134-3147.

157. Plotkowski MC, de Bentzmann S, Pereira SH, Zahm JM, BajoletLaudinat $\mathrm{O}$, Roger P, Puchelle E. Pseudomonas aeruginosa internalization by human epithelial respiratory cells depends on cell differentiation, polarity, and junctional complex integrity. Am J Respir Cell Mol Biol 1999;20:880-890.

158. Reiniger N, Ichikawa JK, Pier GB. Influence of cystic fibrosis transmembrane conductance regulator on gene expression in response to Pseudomonas aeruginosa infection of human bronchial epithelial cells. Infect Immun 2005;73:6822-6830.

159. Halldorsson S, Gudjonsson T, Gottfredsson M, Singh PK, Gudmundsson GH, Baldursson O. Azithromycin maintains airway epithelial integrity during Pseudomonas aeruginosa infection. $A m \mathrm{~J}$ Respir Cell Mol Biol 2010;42:62-68.

160. Asgrimsson V, Gudjonsson T, Gudmundsson GH, Baldursson O. Novel effects of azithromycin on tight junction proteins in human airway epithelia. Antimicrob Agents Chemother 2006;50:1805-1812.

161. Elia C, Bucca C, Rolla G, Scappaticci E, Cantino D. A freeze-fracture study of human bronchial epithelium in normal, bronchitic and asthmatic subjects. J Submicrosc Cytol Pathol 1988;20:509-517.

162. de Boer WI, Sharma HS, Baelemans SM, Hoogsteden HC, Lambrecht BN, Braunstahl GJ. Altered expression of epithelial junctional proteins in atopic asthma: possible role in inflammation. Can $\mathrm{J}$ Physiol Pharmacol 2008;86:105-112.

163. Hackett TL, Singhera GK, Shaheen F, Hayden P, Jackson GR, Hegele RG, Van Eeden S, Bai TR, Dorscheid DR, Knight DA. Intrinsic phenotypic differences of asthmatic epithelium and its inflammatory responses to respiratory syncytial virus and air pollution. $\mathrm{Am} J$ Respir Cell Mol Biol 2011;45:1090-1100.

164. Parker JC, Thavagnanam S, Skibinski G, Lyons J, Bell J, Heaney LG, Shields MD. Chronic IL9 and IL-13 exposure leads to an altered differentiation of ciliated cells in a well-differentiated paediatric bronchial epithelial cell model. PLOS ONE 2013;8:e61023.

165. Post S, Nawijn MC, Jonker MR, Kliphuis N, van den Berge M, van Oosterhout AJ, Heijink IH. House dust mite-induced calcium signaling instigates epithelial barrier dysfunction and CCL20 production. Allergy 2013;68:1117-1125.

166. Blume C, Swindle EJ, Dennison P, Jayasekera NP, Dudley S, Monk P, Behrendt $\mathrm{H}$, Schmidt-Weber CB, Holgate ST, Howarth PH, et al. Barrier responses of human bronchial epithelial cells to grass pollen exposure. Eur Respir J 2013;42:87-97.

167. Fujita $H$, Chalubinski M, Rhyner $C$, Indermitte $P$, Meyer $N$, Ferstl $R$, Treis A, Gomez E, Akkaya A, O'Mahony L, et al. Claudin-1 expression in airway smooth muscle exacerbates airway remodeling in asthmatic subjects. J Allergy Clin Immunol 2011;127:1612-1621, e8.

168. Xiao C, Puddicombe SM, Field S, Haywood J, Broughton-Head V, Puxeddu I, Haitchi HM, Vernon-Wilson E, Sammut D, Bedke N, et al. Defective epithelial barrier function in asthma. J Allergy Clin Immunol 2011;128:549-556, e12.

169. Hackett TL, de Bruin HG, Shaheen F, van den Berge M, van Oosterhout AJ, Postma DS, Heijink IH. Caveolin-1 controls airway epithelial barrier function: implications for asthma. Am J Respir Cell Mol Biol 2013;49:662-671. 